\title{
CONSTITUTING SOCIALISM FOR THE TWENTY-FIRST CENTURY: EXAMINING CUBA'S 2019 CONSTITUTION
}

\author{
Mark Ginsburg \\ University of Maryland
}

\begin{abstract}
Mark Ginsburg is a Visiting Scholar in the International Education Policy program at University of Maryland (USA). Although he is now retired, he continues to work with graduate students on their research. He has also served on the faculty at the University of Aston (Birmingham, England); University of Houston; University of Pittsburgh; University of Oslo (Norway); Teachers College, Columbia University; Kobe University (Japan); George Washington University; and Universidad de Ciencias Pedagógicas "Enrique José Varona” (Cuba). Previously, he was president of the Comparative and International Education Society (CIES, 1991-2) and coeditor of the Comparative Education Review (2003-13). He has (co) authored or (co)edited eight books, five special issues of journals, and over 140 journal articles and book chapters.
\end{abstract}

\begin{abstract}
This article summarises the results of a qualitative content analysis of the 2019 Cuban Constitution, approved in a national referendum on 24 February 2019, and compares Cuba's constitutionally identified structures and processes with those highlighted as core characteristics of what has been termed twenty-first-century socialism. The article draws mainly on the work of Marta Harnecker (2010 and 2015), who includes the following features of twenty-first-century socialism: a) promoting participative democracy; b) creating the political instrument needed to lead the transition; c) instituting social ownership of the means of production; d) organising the economy toward satisfying human needs; e) having a decentralised (but aggregating) planned economy (including establishing worker-organised production as well as conceiving of efficiency as respect for nature and investment in full human development); f) incorporating material and moral incentives; g) educating for full human development
\end{abstract}


and cultural transformation; and h) building regional (and international) integration. Cuba's 2019 Constitution overall measures up well with respect to these characteristics. The article concludes that Cuba's 2019 Constitution identifies structures and processes that are in line with the characteristics of twenty-first-century socialism. There is also evidence that Cuba represents a "unique model" (Burbach et al. 2013a), one that has been evolving since the 1959 Revolution, including during the Special Period of the 1990s and during the decade prior to the 2019 Constitution being approved, and one that has developed in the context of the US blockade and other hostile actions.

Keywords: Cuba's 2019 Constitution, twenty-first-century socialism, participative democracy, social ownership of means of production, internationalism, educating for full human development

\section{Introduction}

In this article ${ }^{1}$ I examine relevant sections of the 2019 Constitution of the Republic of Cuba, which came into effect on 10 April 2019 (Constitute Project 2019).2 Approximately six weeks earlier, on 24 February 2019, 90.2 percent of the $8,705,723$ eligible adult (age 16+) Cuban citizens went to the polls to participate in a referendum, in which $90.6 \%$ of those voting registered their approval of the new Constitution. The 2019 Constitution replaces the 1976 Constitution, which had previously been reformed by popular votes in 1978, 1992 and 2002. The February 2019 referendum had been preceded by 133,681 community- and group-based popular consultations (August-November 2018), during which $1,708,997$ proposals were made for revisions, and by extensive debate and a vote by the National Assembly of People's Power in December 2018 (Granma, 26 February 2019; see also Yaffe 2020: 250-1).

1 Paper prepared for presentation as part of the thematic track, 21st Century Socialism and Education: Global Alternatives to Patriarchy, Racialized Capitalism, and Climate Change, organized for the (COVID-19 cancelled) Comparative and International Education Society (CIES) annual conference, Miami, March 2020, and then presented at the 2021 CIES (virtual) conference, Seattle, 25-29 April 2021.

2 Cuba's 2019 Constitution includes 229 articles organized into eleven titles. The analysis presented in this article focuses on the Preamble and selected, relevant articles in six of the titles of the Constitution: Political Foundations; Economic Foundations; Principles of Educational, Scientific and Cultural Policy; Rights, Duties, and Guarantees; Structure of the [National] State; and Electoral System. The five other titles of the 2019 Constitution, which were reviewed but not analysed in depth for this article, are: Citizenship; State Territorial Organization; Local Organs of People's Power; Defense and National Security; and Reform of the Constitution. 
That Cuba is conceptualised as socialist is signalled in the Preamble of the 2019 Constitution:

We, the people of Cuba, inspired by the heroism and patriotism of those who fought for a free, independent, sovereign, democratic homeland of social justice and human solidarity, ... [for] those who promoted, participated in, and developed the first organizations of laborers, peasants and students; disseminated socialist ideas; and founded the first revolutionary, Marxist and Leninist movements ... [which] led us to the victorious popular revolution of January $1959 \ldots$ (Preamble; emphasis added) ${ }^{3}$

Article 1 of the Constitution reinforces the idea that Cuba is to be considered a socialist state:

Cuba is a democratic, independent, and sovereign socialist state of law and social justice, organized by all and for the good of all, as a unitary and indivisible republic, founded by the labor, dignity, humanism and ethic of its citizens for the enjoyment of liberty, equity, justice and equality, solidarity, well-being and individual and collective well-being and prosperity. (Article 1; emphasis added)

The question I seek to address in this article is how Cuba, as constituted in the 2019 Constitution, compares with descriptions of key characteristics of twentyfirst-century socialisms, ${ }^{4}$ particularly those presented by Marta Harnecker (2010, 2013, 2015; see also Bellamy Foster 2010; Burbach et al. 2013b; Fidler 2015; Gilbert 2020; Lebowitz 2010; Ross and Rein 2013).

3 All excerpts from Cuba's 2019 Constitution are from the version in English distributed by Constitute Project (constituteproject.org). The document is described as the "draft of 2018 with amendments resulting from the popular consultation, published on January 5, 2019 [and] approved by the public in a national referendum on February 24, 2019. This complete constitution has been generated from excerpts of texts from the repository of the Comparative Constitutions Project" (p. 1). For the official version of the 2019 Constitution in Spanish, see: https://www.gacetaoficial.gob.cu/es/ constitucion-de-la-republica-de-cuba-proclamada-el-10-de-abril-de-2019.

4 As Burbach et al. (2013b: 5) explain, while there are characteristics that are generally shared, countries like Bolivia, Ecuador and Venezuela, which are associated with twenty-first-century socialism, differ in how they incorporate these characteristics: "The three countries that have put twenty-first-century socialism on the agenda have had decidedly different results, as the following chapters reveal." Thus, one can speak of twenty-first-century socialisms - in the plural (see also Harnecker 2010: 29; Lebowitz 2010: 25-6). 


\section{Framework for Conceptualising Twenty-First-Century Socialisms}

In her frequently cited 2010 publication, Twenty-First Century Socialism: Inventing to Avoid Mistakes, and in her more recent 2015 work, A World to Build: New Paths toward Twenty-First Century Socialism, Marta Harnecker presents a set of characteristics of 21st century socialism. Harnecker (2015: 59-60) recounts that "Venezuelan President Hugo Chávez used the phrase '21st century socialism' or 'socialism for the 21st century' in a public forum for the first time on 25 February 2005 at the Fourth Social Debt Summit ... [H] said there was no other alternative to capitalism besides socialism... [but] warned it would have to be different from previous socialisms, that we would have to 'invent 21st century socialism'” (see also Bellamy Foster 2010; Burbach et al. 2013b; Cole 2012; Griffiths and Williams 2009; Harnecker 2010).5 Indeed, twenty-first-century socialism is less often defined explicitly, but more often framed in contrast to twentieth-century socialism (associated with the Soviet Union and the model adopted by many Eastern European nations from the mid1940s until 1989) (e.g. see Burbach et al. 2013b: 4; Harnecker 2010: 25; Harnecker 2013: point 5; Ross and Rein 2013: 69). Moreover, Harnecker (2015: 62) states that " $[t]$ his socialism of the 21 st century, which seeks to guard its distance from the practices of twentieth-century socialism, has recovered some of Marx and Engels' original ideas".

From Harnecker's $(2010,2015)$ perspective the key characteristics of twentyfirst-century socialism include:

- Promoting participative democracy

- Creating the political instrument needed to lead the transition

- Instituting social ownership of the means of production

- Organising economy toward satisfying human needs

- Having a decentralised (but aggregating) planned economy ${ }^{6}$

- Incorporating material and moral incentives

- Educating for full human development and cultural transformation

- Building regional (and international) integration

- Transforming the role of the military.

5 Harnecker (2015: 60) clarifies, however, that "some authors had already used [the term]; for example, the Chilean sociologist Tomás Moulian in his book 21st Century Socialism: The Fifth Way, which was published in 2000" (see also Harnecker 2010: 27).

6 As will be discussed further below, such planning would need to emphasize a) the establishment of worker-organised production and b) a conception of efficiency that includes respect for nature and investment in full human development. 


\section{Analysing Cuba's 2019 Constitution in Terms of the Characteristics of Twenty-First-Century Socialism}

In this section I describe each of the above-listed characteristics of twenty-firstcentury socialism and then present excerpts from the Cuba's 2019 Constitution that show how, and to what degree, these characteristics are reflected in this document. While my focus is on the text of the 2019 Constitution, I will draw on published literature to illuminate how Cuba's political economy functions in practice, currently and previously.

\section{Promoting Participative Democracy}

Burbach et al. (2013b: 10) highlight "the profoundly democratic character of twentyfirst-century socialism". ${ }^{7}$ Moreover, for Ciccariello-Maher (2016), the essence of socialism in Venezuela, often identified as an exemplar of twentyfirst-century socialism, is "radical democracy" (see also Ellner 2013), in that it includes "bottom-up structures of participation" (Rosen 2013: 23). In her examination of Venezuela as an example of twenty-first-century socialism, Harnecker (2010: 37-8) elaborates:

The Bolivarian Constitution [of Venezuela] ... emphasizes popular participation in public affairs and stresses that it is this protagonism that will guarantee complete individual and collective development. Although there are several articles in the Constitution that refer to this subject, probably the most specific one is Article 62. It says that "the people's participation in creating, implementing, and controlling public policy is the necessary way to achieve the protagonism that ensures its full development both individual and collective." It goes on to say that it is "the state's obligation and society's duty to create the conditions most favorable to this participation." 8

7 One should note that "Karl Marx ... was a vocal supporter of the movements for democracy in his own time" (Leopold 2020). See also Draper (1974) and Hudis (2020).

8 Burbach et al. (2013b: 73) provide additional details about protagonistic or participatory democracy in Venezuela: "In order to give greater power to communities, in late 2005 [Hugo] Chávez began calling on citizens to form communal councils. The Law of Communal Councils was approved in April 2006, defining these councils as 'instances for participation, articulation, and integration between the diverse community-based organizations, social groups and citizens, that allow the organized people to directly exercise the management of public policies and projects"' (see also Azzellini 2013; Ellner 2013; Hetland 2016; Rosen 2013). 
As noted in the Introduction, Cuba's 2019 Constitution was developed and approved with extensive and broad-based popular participation. And the Constitution states in Article 3 that:

In the Republic of Cuba, sovereignty resides nontransferably with the people, from which all the State's power emanates. The people exercise this power directly and via Assemblies of People's Power and other organs of the State that are derived from them, in the form and according to the norms established by the Constitution and laws. (Article 3, emphasis added)

According to Article 14 of Cuba's 2019 Constitution, the National Assembly of People's Power is assigned, among other responsibilities, "the tasks that edify, consolidate, and defend the socialist society". While the National Assembly of People's Power is accorded ultimate authority for policy and other decisions, the structure of Cuba's political system identifies the municipal and provincial bodies (and, as is mentioned below, workplace bodies, neighbourhood institutions and mass organisations) as key sources of the ideas for such decisions. ${ }^{9}$ Moreover, especially at the municipal level, Section 5 of Title VIII of Cuba's 2019 Constitution discusses "Guarantees of Right to Petition and Local Popular Participation". ${ }^{10}$ As delineated in Article 200:

The Municipal Assembly of People's Power, in order to guarantee the rights of petition and citizens' participation:

a. Convenes a popular consultation for matters of local interest in accordance with the Assembly's powers;

9 Cuba's 2019 Constitution defines the authority, responsibilities, members and officers, the process of their selection and their length of service of the National Assembly of People's Power (Section One: Articles 102-12 and Section Two: Articles 113-19 of Title VI: Structure of the State), the Provincial Government of People's Power (Articles 170-81 of Title VIII: Local Organs of People's Power), the Municipal Assembly of People's Power (Chapter 2: Articles 182-96 of Title VIII), Commissions of the Municipal Assembly of People's Power (Section Three: Article 197 of Title VIII), and the People's Council (Section Four: Articles 198-9 of Title VIII).

10 It is important to note that Article 204 in Title IX: Electoral System of Cuba's 2019 Constitution stipulates that: "All citizens with the legal capacity to do so have the right to contribute to the management of the State, either directly or through their elected representatives within the organs of People's Power and to participate, for this purpose, in the form prescribed by the law, through periodic elections, plebiscites, and popular referendums that will be free, equal, direct, and secret. Every elector has the right to a single vote." 
b. Guarantees adequate attention to the proposals, complaints, and requests of the population;

c. Guarantees the right of the municipality's population to propose to the Assembly the analysis of issues within its competence;

d. Maintains an adequate level of information for the population regarding the decisions that are of a general interest to them when they are adopted by the organs of People's Power;

e. Analyzes, upon a petition of the citizens, its own agreements and orders or those of the subordinate municipal authorities if they are claimed to harm the interests of the citizens, both individual or collective in nature, and adopts the corresponding means of resolving them; and

f. Implements, within its competence, any other action that is necessary to guarantee these rights.

Additionally, Article 10 highlights the accountability of the state and officials to the people: "The organs of the State, its leaders, functionaries, and employees are obligated to respect, care for, and respond to the people, to maintain close links with the people, and to submit to their oversight in the forms established by the Constitution and the laws." 11 And, in Article 101, the 2019 Constitution describes how the political system is based on "principles of socialist democracy", noting the role people play in electing, monitoring and securing accountability of the state and its officials:

The organs of the State are formed and develop their activities upon the foundation of the principles of socialist democracy, which are expressed in the following rules:

a) All the representative organs of State power are elected and renewable;

b) The people monitor the activity of the State organs, their leaders, functionaries, representatives, and delegates, in accordance with that which the law prescribes;

c) Elected representatives have the duty to periodically release required documentation regarding the performance of their duties and may be removed from office at any moment;

11 As an illustration, Yaffe (2020: 1) reports that "since becoming president in the spring [of 2018, Miguel] Díaz-Canel has plunged in among the Cuban people, across the length and depth of the island, visiting workplaces, communities, schools and other centres. He has urged all Cuba leaders to get closer to the people, and to ensure that local development strategies relate to each community's culture and history, to the aspirations, motivations and opinions of local people. Implementation, he has pointed out, will depend on their support and participation.” 
d) Each State organ develops, according to its role and within the framework of its competency, initiatives designed to take advantage of resources and local possibilities and the incorporation of the social and mass organizations to their activity;

e) The orders of the superior State organs are obligatory for the subordinate State organs...

Furthermore, the 2019 Constitution indicates that the participative nature of Cuban society is not limited to relations between individual citizens and state officials. It identifies civil society, in the form of mass and social organisations, as also playing an important role in Cuban society. For instance, Article 14 notes that " $[\mathrm{t}]$ he State recognizes and stimulates the social and mass organizations that bring together distinct sectors of the population, that represent their specific interests and that involve them in the tasks that edify, consolidate, and defend the socialist society". ${ }^{12}$

It is important to note, however, that Cuba's experience with participatory democracy has a longer history, dating back to at least 1991, when the Communist Party of Cuba (PCC) "held its Fourth Congress, preceded by a widescale debate among the population based on a document that dealt with economic and political issues.... This resulted in several resolutions to reform the Constitution and elaborate a new electoral law" (August 2013: 151). ${ }^{13}$ And, as Yaffe (2020: 65-6) explains,

[t]his became the modus operandi, extensive public consultations prior to significant economic reforms. It was repeated with the 'Workers' Parliaments' established between January and March 1994, prior to the National Assembly,

12 Among the most important mass organizations are the Federation of Cuban Women (Federación de Mujeres Cubanas or FMC), the National Association of Small Farmers (Asociación Nacional de Agricultores Pequeños or ANAP), the Confederation of Cuban Workers (Confederación de Trabajadores de Cuba or CTC), the Federation of University Students (Federación de Estudiantes Universitarios or FEU), Federation of Pre-University Students (Federacion de Estudiantes de la Ensenanza Media or FEEM), the Association of Cuban Pedagogues (Asociación de Pedagogos de Cuba or APC) and the Committees for the Defense of the Revolution (Comites de Defensa de la Revolución or CDRs) (August 2013: 147).

13 August (2013: 218) notes that participation in the six months of debate included representatives in the municipal, provincial and national assemblies of People's Power and those involved in mass organisations as well as the many people engaged through "an important relatively new structure ... [t] he consejos populares (CPs - people's councils) ... constituted within the municipalities”. 
which introduced important economic reforms. Three million workers (85 percent of the workforce) met in multiple sessions in 80,000 workplaces to discuss the issues their delegates would debate.

Furthermore, in 2007 Raúl Castro initiated "a consulta (consultation) with the Cuban people. Barrio committees, factory workers, local party organizations, and others were encouraged to meet and register their thoughts and complaints. By August 2009, 5.1 million people out of a total Cuban population of 11.2 million had participated in the consultation" (Burbach et al. 2013a: 144; see also August 2013: 122-3). Additionally, prior to the Sixth Congress of the PCC in April 2011, "the 291 Draft Guidelines for Economic and Social Policy were published on November 1, 2010 ... People at all levels from the grass roots to the [National Assembly of People's Power] . . . There were 163,0471 meetings with 8,913,838 participants. They contributed 3,019,471 separate inputs" (August 2013: 124; see also Yaffe 2020: 213). Another example is that in 2016, following the Seventh Congress of the CCP, four major documents, including a national plan of economic and social development to 2030 (Plan 2030) and a conceptualisation of Cuba's social and economic model of socialist development (Conceptualisation), “were debated by 1.6 million Cubans in some 47,000 meetings of the CCP and the UJC, and by representatives of 'organisations of the masses' (FMC, CDRs, CC, ANAP among many) and in other sectors" (Yaffe 2020: 225; see also Campbell 2021).

\section{Creating the Political Instrument Needed to Lead the Transition}

Harnecker (2010: 36) states that "twenty-first century socialism . . cannot . . . come into being because a government or an enlightened vanguard says so; it cannot be decreed from above; it is a process that is built with the people, in which, as they transform their circumstances, they transform themselves. It is not a handout". However, at the same time, Harnecker (2010: 65) argues that there is a need for a political instrument - "some kind of political organization, which, with the support of the people, conquers state power - or at least government power". Harnecker goes on to explain that this is because:

Building socialism entails developing new relations of production, carrying out a real cultural revolution that allows us to go beyond the inherited culture, and developing a revolutionary subject who is the bedrock of the whole process. It also requires that the people undertake an apprenticeship in forms of self-government. These are not things that come about spontaneously. (2010: 65) 
Although the 1959 Cuban Revolution was led organisationally by the 26 July Movement, over time the instrument positioned as the "leading political force" responsible for guiding "common efforts in the construction of socialism" was the Communist Party of Cuba. This key role of the Communist Party of Cuba is spelled out in Article 5 of the 2019 Constitution:

The Communist Party of Cuba, unique, Martiano, Fidelista, and Marxist-Leninist, the organized vanguard of the Cuban nation, sustained in its democratic character as well as its permanent linkage to the people, is the superior driving force of the society and the State. It organizes and orients the communal forces towards the construction of socialism and its progress toward a communist society. It works to preserve and to fortify the patriotic unity of the Cuban people and to develop ethic, moral, and civic values. (Article 5, emphasis added)

Burbach et al. (2013b: 8) argue - in 2013 - that

[w] here Cuba is not embracing the challenge of twenty-first-century socialism is in the role of the Communist Party, which is set on retaining control over the direction of the state and the political system. This differs from the emerging socialist societies in the rest of Latin America, which are committed to holding multiparty, national elections to advance their struggles.

However, one should note, as August (2013: 195) explains, that since 1992, the Communist Party of Cuba (PCC) has not been directly "involved in either nominating candidates or electing them" (p. 146) and "cannot propose or approve legislation [but] ... can recommend overall policies to the [National Assembly of People's Power]".

\section{Instituting Social Ownership of the Means of Production}

Harnecker (2010: 43; emphasis added) explains that "if our aim is to create an economic model ... satisfying the needs of all the country's inhabitants, it is absolutely essential that these means of production - or at least the most important ones - are not hoarded by a few people and used for their own benefit but are collective property, owned by all the people". ${ }^{14}$ In a later publication

14 This characteristic of twenty-first-century socialism was also highlighted by Marx and Engels in the middle of the nineteenth century. It should be noted that Marx and Engels were "contemptuous of utopian [socialists'] habit of indulging in detailed 'future-painting,' [picturing] a socialist society as 'an ideal to which reality will have 
Harnecker (2015: 93) clarifies the meaning of the concept of ownership of the means of production:

This concept can be related to several issues, including the ability to use, to enjoy, and to dispose of the means of production, and therefore the products obtained in the production process.... We will use "real ownership" to refer to the situation in which the effective possession of the means of production is in the hands of those who also have the power to dispose of them and their products.

Moreover, Harnecker (2010: 44) contrasts twenty-first-century socialism with twentieth-century socialism (namely, in the Soviet Union), which

tended to identify collective property with state property ... [In the latter case] the productive process itself went through very few changes. A large capitalist factory was not very different from a large socialist factory: the workers continued to be just a few more cogs in the wheel, and they had very little or no participation in decision making in their workplaces.

The words in the first quote of this subsection are emphasised to indicate that it is not a characteristic of twenty-first-century socialism that all the means of production, economic activity, and property be collectivised and owned by the people. Thus, within a twenty-first-century socialism some private property and some small private enterprises may exist. Indeed, this has been documented in the cases of Chile (Popular Unity Government, 1971/2013), Venezuela (Azzellini 2013; Gill 2016; Ross and Rein 2013), Bolivia (Faiola 2019; Ross and Rein 2013), Nicaragua (Zwerling and Martin 1985), and Grenada (Bishop 1983), which are viewed as representing precursors or versions of twenty-first-century socialism in Latin America and the Caribbean (Burbach et al. 2013b).

Cuba's 2019 Constitution defines the nature of Cuba's economic system in various articles and goes into more detail in the articles in what is termed Title II: Economic Foundations. For example, Article 18 notes that the "Republic of

to adjust" (Marx and Engels 1942: 26; quoted in Howe 1977/1985: 178; see also Forman 1973: 4). However, in The Communist Manifesto they identified ten measures that they envisioned to be "generally applicable" to at least "the most advanced countries" that undertook revolutions to achieve socialism, including the following: 1) abolition of [private] property in land and application of all rents of land to public purposes; and 5) centralization of credit in the hands of the state, by means of a national bank with state capital and an exclusive monopoly (Marx \& Engels 1848/1983: 30-1). 
Cuba is governed by a socialist economic system based on ownership by all people of the fundamental means of production as the primary form of property" (Article 18, emphasis added). However, Cuba's 2019 Constitution is somewhat ambiguous about what it means for the "whole people" to own (and exercise control over) the "means of production". While Article 19 indicates that "[t]he State directs, regulates, and monitors economic activity, reconciling national, territorial, collective, and individual interests for the benefit of society"; Article 20 indicates that "[w]orkers participate in the processes of economic planning, regulation, management, and monitoring". And, as discussed in the sections on "promoting participative democracy" and "having a decentralized (but aggregating) planned economy”, mass organisations (e.g. ANAP, CDRs, CTC, FEEM, FEU, FMC) and neighbourhood people's councils are involved in economic planning and policy deliberations in addition to the municipal, provincial and national assemblies of people's power.

Nevertheless, Cuba's 2019 Constitution is quite clear in stating that other forms of ownership (besides ownership/control by the state and the people) are allowed or even encouraged. Thus, Article 22 specifies that the following "are recognized as forms of property":

a) Socialist property of the entire population: in which the State acts as a representative and beneficiary of the people as property owner;

b) Cooperative property: that which is sustained through the collective labor of partner owners and through the effective exercise of the principles of cooperativism; $;^{15}$

c) Property of political, social, and mass organizations: ownership that they exercise over their goods designed to fulfill their roles;

d) Private ownership: that which is exercised over specific means of production by natural or legal persons, Cubans or foreigners; with a complementary role in the economy;

e) Mixed property: that which is formed through the combination of two or more forms of ownership;

f) Institutional and associative property: that which these groups exercise over their goods for non-profit purposes; and

g) Personal property: that which is exercised over one's belongings that, without constituting means of production, contribute to the satisfaction of the material and spiritual necessities of their owner.

15 For a discussion of Cuba's experience with agricultural and non-agricultural cooperatives, historically and today, see Campbell (2018) and DuRand (2018). 
It is important to note that inclusion of the private sector in Cuba's economy predates the 2019 Constitution. For instance,

the Constitution of 1976 left some $20 \%$ of arable land in the hands of small private farmers or agricultural cooperatives. In 1982, foreign investment was first approved for joint ventures with the Cuban state. In 1992, the Constitution was amended to state that mandatory state ownership applied only to the "fundamental means of production". (Yaffe 2020: 328; see also Fitz 2020: 132-3)16

Moreover, Campbell (2021: 120) reports that " $1 \%$ of the [non-agriculture] workforce in $1989 \ldots$. . [was] self-employ[ed]" and that this figure "exploded to about 5\% by the end of 1995" (see also Campbell 2018: 163).

\section{Organising the Economy toward Satisfying Human Needs}

Harnecker (2015: 83) indicates that " $[\mathrm{t}]$ wenty-first century socialism proposes to replace the neoliberal capitalist model with a new socialist model ... [that places] [h] uman development as the center and focus . . . [and has] as its aim the satisfaction of human needs, not profits". Of course, as Harnecker (2015: 65-6) discusses, the prioritisation of satisfying human needs (versus profits) was, at least rhetorically, at the heart of twentieth-century socialism and was central to the Marx and Engels's earlier ideas. For example, Engels (1880/1972: 634) observed that under socialism "the social anarchy of production [characteristic of capitalism] gives place to a social regulation of production upon a definite plan, according to the needs of the community and of each individual".

As noted in the previous section, Article 18 of Title II of Cuba's 2019 Constitution delineates the nature of Cuba's economic system, further clarifying that the Republic of Cuba has a "socialist economic system ... . [which entails] the planned direction of the economy, [and] which considers, regulates, and monitors the economy according to the interests of the society" (Article 18, emphasis added). Moreover, as indicated above, Article 22 specifies that one important form of ownership is "Socialist property of the entire population: in

16 Yaffe (2020: 255) comments that "[ $\mathrm{t}]$ he Cuban Revolution is cautiously advancing along a tightrope, balancing between plan and the market”. And as Fitz (2020: 133-4) suggests, this balancing act is occurring internationally in "health tourism" as well as domestically in the "massive proliferation of self-employment: not only work in paladares, but also taxi-driving, repair services, and sale of personal hygiene products. ... The policy of encouraging tourism meant that citizens could rent out empty rooms in their homes (a bit similar to bed-and-breakfasts) under strict government regulations." 
which the State acts as a representative and beneficiary of the people as property owner". In addition, in identifying the variety of constitutionally guaranteed rights, Cuba's 2019 Constitution reinforces the principle that the purpose of the economy (and government) is to provide for the various needs of the Cuban people. These rights include:

- to obtain a dignified employment according to their choice, qualifications, aptitude, and the demands of the economy and society (Article 64);

- for their work to be remunerated according to its quality and quantity (Article 65);

- to a break, which is guaranteed through the eight-hour workday, a weekly break and annual paid vacations (Article 67);

- to safety and health at work through the adoption of suitable means to prevent work-related accidents or illnesses (Article 69);

- to adequate housing and a safe and healthy home for all people (Article 71);

- to quality medical attention, protection and recovery services, free of charge (Article 72);

- to free, accessible, and quality education services for their holistic development, from preschool until the postgraduate level (Article 73);

- to physical education, sports, and recreation as essential elements of their quality of life (Article 74);

- to enjoy a natural environment that is healthy and stable (Article 75);

- to potable water and to its sanitation (Article 76);

- to a healthy and adequate diet (Article 77);

- to consume quality goods and services that are not counter to their health (Article 78); and

- to participate in the artistic and cultural life of the nation (Article 79).

It is noteworthy, however, that Cuba has at times had to balance the goal of satisfying people's needs with dealing with economic challenges, especially in the context of the 60+ year US blockade or embargo. For instance, Yaffe (2020: 48; emphasis added) reports that during the Special Period, "[f]ollowing the national consultation of 1993, measures were taken to improve the country's fiscal balance without introducing severe cuts to 'los logros' (welfare programs) of the Revolution", but some cuts had to be made. And August (2013:144) states that when in 2011 Cuba updated its economic model in the face of problems encountered in the 2008-11 period, the changes did not constitute "a rejection of socialism ... The Cuban economy [remained] geared to improving the satisfaction of the people's basic needs in the realms of food, housing, education, health, sports, social security, social assistance, culture and all other aspects." However, as Yaffe (2020: 232) notes, "[b]etween 2009 and 2014 spending on social 
assistance was reduced dramatically by 60 per cent, and the number of recipients plummeted from 426,000 to 169,778 in the same period".

\section{Having a Decentralised (But Aggregating) Planned Economy}

Harnecker (2015: 86) explains that in "21st century socialism, it must be the people themselves who define and prioritize what is produced through a participatory planning process". ${ }^{17}$ This planning process, as noted above, should not be undertaken mainly by government officials or industrial managers, but should be the responsibility of workers in collaboration with other members of the community. As Wolff (2019: 96-7) explains:

To go beyond socialism's twentieth-century achievements and failures, strengths, and weaknesses, socialists must do more than change who functions as employer within the employer/employee system of capitalism. ... [In the] twenty-firstcentury concept of socialism ... [d]emocratic collectives comprising worker co-ops would replace the capitalists as decision-makers within each enterprise. The collective workers directing each enterprise would negotiate the collective's relationships with (1) other enterprises, (2) individual workers within the enterprise, (3) consumers of the enterprise's products, and (4) residential communities (local, regional, national, and international) that interact with the enterprise.

Additionally, while decisions within a particular enterprise should be made by the workers (in the consultation with consumers and the local community members), there is also need for a process of aggregating and reconsidering enterprise/ local decisions at provincial and national levels.

Moreover, within twenty-first-century socialism, such planning would be based on a "respect for nature, and opposition to consumerism" as well as a "new concept of efficiency that both respects nature and seeks human development" (Harnecker 2015: 83-4). The basic idea is that economic planning should take into consideration the impact on the environment of economic production and consumption but also give serious attention to whether and how the process

17 Harnecker (2015: 82) reminds us that this characteristic of twenty-first-century socialism does not contradict Marx's ideas promulgated in the nineteenth century, noting "that when [in the Civil War in France,] Marx [1871/1972] discussed the need to destroy 'state power' he was referring to 'centralized state power.' The word centralized is key, as this is the fundamental characteristic of the inherited state. His statement is that 'the old centralized governments in the provinces would also have to give way to the self-government of the producers.'” 
of production and distribution enhances opportunities for the development of the humans who are engaged in such activities.

As discussed previously, Cuba's 2019 Constitution specifies that "[t]he Republic of Cuba is governed by a socialist economic system ... [involving] the planned direction of the economy" (Article 18, emphasis added). Furthermore, while Article 19 stipulates that "[t]he State directs, regulates, and monitors economic activity, reconciling national, territorial, collective, and individual interests for the benefit of society" (Article 19, emphasis added), Article 20 emphasises that "[w]orkers participate in the processes of economic planning, regulation, management, and monitoring" (Article 20, emphasis added). ${ }^{18}$

Additionally, Cuba's 2019 Constitution articulates a decentralised (but aggregating) planning process. ${ }^{19}$ That is, planning begins at the work unit level as well as, with respect to government, at municipal assembly of people's power, and then these plans are moved up to the broader industrial organisation as well as, with respect to government, the provincial and national assemblies of people's power. Additionally, according to Cuba's 2019 Constitution, such planning decisions should be informed by - or, at least, undertaken with reference to - the economy's impact on the environment (see Article 16) ${ }^{20}$ and the economy's impact on human development and welfare of workers and others in the community (see Articles 64, 65, 67, 69 and 71-9). ${ }^{21}$

18 As an example, previously, "[t] he introduction of the new Labour Code in June 2014 followed five months of debate involving 2.8 million workers in nearly 70,000 workplace assemblies and in the CTC, the Ministry of Labour and the National Assembly. The process led to over 100 amendments to the draft Code" (Yaffe 2020: 223).

19 While Burbach et al. (2013a: 143) observe that, "with its roots in twentieth-century socialism, the Cuban Communist Party exercised complete control of the state and the economy", they explain that at its Sixth Congress in April 2011 the Communist Party of Cuba considered "313 lineamientos - guidelines or recommendations. ... This opening in Cuba began with the ascent of Raúl Castro, [who] . . made a series of important changes from 2007 to 2009 to streamline and decentralize activities of the government". Previously, the 1992 reform of the Constitution had "eliminate[d] 'democratic centralism' as an explicit principle on which the political system operates, replacing this concept with 'socialist democracy"' (August 2013: 152).

20 As presented earlier, Article 16 (point " $\mathrm{f}$ ") of Cuba's 2019 Constitution states that "[Cuba] promotes the protection and conservation of the environment and the confrontation of climate change, which threatens the survival of the human species".

21 As noted earlier, Cuba's 2019 Constitution reinforces the principle that the purpose of the economy is to provide for the various needs of the all Cuban people: a) to obtain a dignified employment according to their choice, qualifications, aptitude and the demands of the economy and society (Article 64); b) for their work to be remunerated according to its quality and quantity (Article 65); c) to a break, which is 
It is worth noting, moreover, that Cuba's commitment to an environmentally sensitive economy predates the 2019 Constitution. Indeed, during the Special Period of the 1990s, Cuba moved to reduce its carbon footprint in agricultural and industrial activities, such that in 2006 "Cuba was recognized as the only nation in the world living sustainably" (Yaffe 2020: 64). And, more recently, two of the "strategic areas" identified in the Conceptualisation and Plan 2030 documents, which were debated, revised and approved during 2016-17, focused on "natural resources and the environment" as well as "human development, justice and equity" (Yaffe 2020: 228). Additionally, it is noteworthy that Cuba ranked ninth of 164 countries on the Sustainable Development Index (SDI) in 2019. This index "measures the ecological efficiency of human development ... The SDI starts with each nation's human development score (life expectancy, education and income) and divides it by [its] ecological overshoot" (Sustainable Development Index n.d.). Specifically, Cuba was in the lower range on the two measures of ecological offshoot: $\mathrm{CO}_{2}$ tons of emission per capita $=3.42$ (other countries ranging from 0.13 to 28.78 ) and material footprint tons per capita $=8.04$ (other countries ranging from 0.93 to 37.92 ) (Sustainable Development Index n.d.).

\section{Incorporating Material and Moral Incentives}

Harnecker (2015: 91) suggests that under twenty-first-century socialism "moral incentives can increasingly become a force that moves people into action". 22 However, she clarifies that:

guaranteed through the eight-hour workday, a weekly break and annual paid vacations (Article 67); d) to safety and health at work through the adoption of suitable means to prevent work-related accidents or illnesses (Article 69); e) to adequate housing and a safe and healthy home for all people (Article 71); f) to access quality medical attention, protection and recovery services, free of charge (Article 72); g) free, accessible and quality education ... from preschool until the postgraduate level (Article 73); h) to physical education, sports and recreation as essential elements of their quality of life (Article 74); i) to enjoy a natural environment that is healthy and stable (Article 75); j) to access to potable water and to its sanitation (Article 76); k) to a healthy and adequate diet (Article 77); to consume quality goods and services that are not counter to their health (Article 78); and to participate in the artistic and cultural life of the nation (Article 79).

22 Fägerlind and Saha (1983: 223) comment that "a socialist development model presumes cooperation and collective effort whereby, at least in theory, equity makes growth possible. It is for this reason that Hoogvelt (1976, p. 163) observes that . . the socialist model 'requires the presence of saints' (that is, total dedication, commitment and cooperation)." Note, however, that twenty-first-century socialism incorporates material as well as moral incentives. 
this goal cannot be realized overnight. Individualism and consumerism have been inculcated into workers and, in general, their motivation to work is tied to economic stimulus. [Thus,] there must be a gradual development of measures combining material and moral incentives that begins to change the culture and values of people, until they feel that the best pay, the best incentive for them, is to see that their work is helping to satisfy the needs of others, making them happy, to realize their work is helping to build a better society for all. (Harnecker, 2015: 91-2)

Cuba's 2019 Constitution states that all adult citizens have the rights of "a dignified employment according to their choice, qualifications, aptitude, and the demands of the economy and society" (Article 64, emphasis added) and "for their work to be remunerated according to its quality and quantity" (Article 65, emphasis added). Thus, material incentives are recognised and guaranteed. At the same time Cuba's 2019 Constitution gives attention to moral incentives in its description of one of the "essential objectives" of the State: "g) [t]o strengthen and preserve the ideology and the ethics inherent to our socialist society" (Article 13, emphasis added). And, as will be discussed below, Cuba's revolutionary history reflects a dialectical dynamic in efforts to develop people to recognise and value moral incentives.

\section{Educating for Full Human Development and Cultural Transformation}

This characteristic of twenty-first-century socialism is related to the previous one. As Harnecker (2010: 65-6) explains:

The main actors in the construction of the new society do not drop from the sky. In fact, they drag a weighty cultural heritage behind them. This is why a process of cultural transformation is needed if socialism is to be built - a process in which the individualistic culture of every person for himself or herself is gradually overcome.... Consumer culture must also be overcome.... Twenty-first century socialism will only be able to consolidate itself if we manage to impregnate present and future generations with a new humanistic and solidarity-infused ethics, an ethics that respects nature and that stresses being rather than having.

Similarly, Cole (2012: 189) observes that “[i]n many ways, the whole Bolivarian project of twenty-first century socialism is, in its very essence, education in the sense of the word. . . . [In 2010 Hugo Chávez,] the revolutionary president of Venezuela[,] . . . described the country as 'a giant school.'” However, it should be noted that this is not unique to twenty-first-century socialism, in that one of the "two underlying principles that guided Soviet education [was] the notion of the "new socialist [hu]man"” (Fägerlind and Saha 1983: 226). 
Cuba's commitment to and achievements in the field of education have been noted by many authors (e.g. Carnoy et al. 2007; Garcia Batista 2002/2016; MacDonald 1985). And its 2019 Constitution continues to stress education. For example, Article 46 lists education as among the rights guaranteed to everyone by the Constitution: "All citizens have the right to life, physical and moral integrity, justice, security, peace, health, education, culture, recreation, sports, and to their holistic development" (Article, 46, emphasis added). Moreover, Article 73 states that Cuban citizens have the right to "free, accessible, and quality education . . . from preschool until the postgraduate level”. Additionally, Cuba's 2019 Constitution specifies that "[t]he State orients, fosters, and promotes education, the sciences, and culture in all of their forms" (Article 32, emphasis added) as well as that:

The State, in order to effectuate this right [to education], establishes a broad system of educational institutions of all types and education levels, which allows the possibility of attending school during any stage of life according to one's aptitudes and the country's social demands and socioeconomic development needs. Society and families have the responsibility of education. (Article 73)

Importantly, Cuba's 2019 Constitution mentions that, in addition to transmitting knowledge and developing skills, the purposes of formal and nonformal education (among other institutions of the State) are:

a) To channel the efforts of the nation in the construction of socialism and to strengthen national unity; ... g) [t]o strengthen and preserve the ideology and the ethics inherent to our socialist society; ... and i) [t] o secure the educational, scientific, technical, and cultural development of the country. (Article 13, emphasis added)

One should note, however, that the issue of moral and political socialisation has been on Cuba's agenda - with varying degrees of emphasis - since the 1959 revolution. For instance, in 1960 Fidel Castro Ruz stated that "the first problem of the revolution is ... how the ideas of the revolution are going to gain ground" (quoted in Aldama de Pino and Casañas Días 2018: 89). And another leader of the Cuban Revolution, Ernesto Che Guevara, promoted the idea that "the society as a whole must become a huge school" in order to develop a "new socialist [hu]man" (see also Tablada 1989). Moreover, what have been termed the first, second, third and fourth educational "revolutions" in Cuba (initiated in mid1970s, mid-1980s, late 1990s and 2008, respectively) sought, in part, to address the problem of worker citizens not being sufficiently motivated by moral incentives (Ginsburg and Garcia Batista 2019; see also Yaffe 2020). 


\section{Building Regional (and International) Integration}

Harnecker (2010: 63) includes the following as one of the "criteria that could allow us to make an objective assessment of the progress of our governments that have explicitly set themselves the goal of building twenty-first century socialism": "Attitude to International (especially Latin American) Coordination and Solidarity: Are they looking for ways to integrate with other countries in the region?" (p. 64). ${ }^{23}$ Other scholars have highlighted this feature as a core element in Venezuela's and Bolivia's twenty-first-century socialist approaches, including attention to their involvement in the Bolivarian Alternative for the Peoples of Our Americas (ALBA, formed in 2004), the People's Trade Treaty (TCP, established in 2006), the Union of South American Nations (UNASUR, formed in 2008) and the Community of Latin American and Caribbean States (CELAC, formed in 2011) (Burbach et al. 2013b; Gill 2016; Pearce 2013; Rosen 2013).

Of course, Cuba is an active participant in these regional organisations; indeed, it was a founding member of ALBA (e.g. see Burbach et al. 2013b). Moreover, Cuba's 2019 Constitution highlights the country's internationalist orientation and engagement. For instance, the Preamble explicitly references the importance of internationalism: "We, the people of Cuba, . . . [who] supported in proletariat internationalism, fraternal friendship, the help, cooperation, and solidarity of the peoples of the world, particularly those of Latin America and the Caribbean ...”Furthermore, Cuba's internationalist orientation, highlighting both anti-imperialism and pro-environmentalism, is referenced in Article 16:

The Republic of Cuba bases its international relations on the exercise of its sovereignty as well as on the antiimperialist and internationalist principles in accordance with the interests of the people and, in consequence: ...

(f) [p]romotes the protection and conservation of the environment as well as responding to climate change, which threatens the survival of the human species...;

23 Of course, internationalism was integral to Marx's and Engels's nineteenth-century ideas about socialism, as indicated by the final statement in the Communist Manifesto: “Working men [and women] of all countries unite!" (Marx and Engels 1848/1983: 44). And, as Burbach et al. (2013b: 57) observe, Hugo Chávez's initiative in 2009, "calling on left parties from around the world to help form a new Fifth International, [was] in the tradition of the internationals forged previously by Marx, Lenin, and Trotsky" in the 19 th and 20 th centuries." 
(h) [c]ondemns direct or indirect intervention in the internal or external affairs of any State and, therefore, also condemns armed aggression, any form of political or economic coercion, unilateral blockades that violate International Law, or any other type of interference or threat to the integrity of the States; ...

(j) [c]lassifies wars of aggression or conquest as an international crime, recognize the legitimacy of battles of national liberation and armed resistance to aggression, and considers it our international duty to act with solidarity with the assaulted party and with the people who fight for their liberation and self-determination; ...

(ñ) [m]aintains and fosters friendly relations with countries that, despite having a different political, social, and economic system, respect our sovereignty, observe the norms of coexistence between States, and adopt a reciprocal attitude with our country, in accordance with the principles of International Law; and

(o) [p]romotes multilateralism and multipolarity in international relations, as alternatives to the domination and political, financial, and military hegemony or any other manifestation that threatens peace, independence, and the sovereignty of peoples.

\section{Transforming the Role of the Military}

Harnecker (2010: 56) states that within twenty-first-century socialism "[o]ne of the most important tasks facing our governments is that of transforming the military ... into an institution at the service of and increasingly identified with the people". ${ }^{24}$ This entails the military defending the country's sovereignty and, at times, maintaining peace in the country, but also taking on responsibilities for engaging in social projects and undertaking big infrastructure projects, as Harnecker (2010: 58, 59) explains below:

Give the Military Responsibility for Social Projects: Assigning social projects to the armed forces so that they use their labor power, their technical knowledge, and their organizational abilities to help the most destitute social sectors is a key measure.

Give the Armed Forces Big Infrastructure Projects: ... [I]n countries like ours, which have so many development needs, it makes no sense for our armies only

24 In order to assist military personnel in serving and identifying with the people, Harnecker (2010: 58) suggests that twenty-first-century socialist governments should: "Provide Education in the Spirit of the Constitution: It is important that top military officers and those under their command have a vision of the world that is consistent with the new society we want to build." 
to train for war and then just sit around and wait for an invasion. Some of the soldiers can be used for strategic economic tasks. Moreover, it is important that the armed forces feel they are not simply defenders of national security but are also builders of the new society. Much of the knowledge they acquire to defend the homeland can be used to repair those elements of the infrastructure that have fallen into disrepair for lack of maintenance (e.g., hospitals and public schools) or to collaborate in managing new strategic companies, or to undertake work that, for example, improves communication systems throughout the country.

Cuba's 2019 Constitution includes this characteristic of twenty-first-century socialism as it spells out in Title $\mathrm{X}$ issues related to "defense and national security". On one hand, Article 217 identifies the military's role in protecting Cuba's sovereignty:

The Cuban State bases its policy of Defense and National Security on the defense of independence, territorial integrity, sovereignty, and peace through the prevention and consistent engagement with the risks, threats, and aggressions that affect their interests.

Its strategic conception of defense is based on the war of all people. (Article 217)

On the other hand, Article 223 (of Title X's Chapter IV: Extraordinary Situations and Disaster) describes the military's broader role, in this case in responding to disasters:

In the case of a disaster of any kind that affects the population or the economic or social infrastructure and that exceeds the capacity or the normal response and recovery of the country or of the territory affected, a Situation of Disaster may be decreed. (Article 223)

Although Cuba's 2019 Constitution does not explicitly address the military's role in engaging in social projects or undertaking big infrastructure projects, I have observed (in person and on television in Cuba) soldiers along with other citizens engaged in social and infrastructure projects when responding to disaster situations. During my two semesters as a visiting professor at the Universidad de Ciencias Pedagógicas “Enrique José Varona”, located in Havana, I witnessed the impact and recovery efforts in relation to two natural disasters: a) Hurricane Irma in September 2017 and b) the tornado that devastated a path in the east of Havana in January 2019. 


\section{Conclusion}

In this article I have examined Cuba's 2019 constitution to assess how it reflects the characteristics of twenty-first-century socialism as described by Harnecker (2010, 2015) and others (notably, Burbach et al. 2013b; Lebowitz 2010). Overall, I conclude that Cuba's 2019 Constitution identifies structures and processes that are in line with the characteristics of twenty-first-century socialism. At the same time, there is evidence that Cuba represents a "unique model, [which is] different . . . from the countries in South America that have taken up the banner of twenty-first-century socialism" (Burbach et al. 2013a: 151). ${ }^{25}$ As I have sought to illustrate, Cuba's model of socialism has been evolving since the 1959 Revolution, including during the Special Period of the 1990s and during the decade prior to the 2019 Constitution being approved, and has been constructed in the context of the US blockade and other hostile actions.

While what is stated in a constitution is not necessarily a complete description of what occurs in practice, it seems useful to understand how twenty-first-century socialism is constituted by Cuba's 2019 Constitution. While I have provided some insights into Cuba's recent and historical experience in practice, there is obviously a need for a more extensive and in-depth examination.

With respect to the characteristic of promoting participative democracy, we observed that Cuba's 2019 Constitution stipulates the right of citizens to participate in influencing and monitoring policy and budgetary priorities, especially at the municipal level, in workplaces and through involvement in mass organisations. Thus, there is provision for "bottom-up structures of participation", though perhaps not as "radical" a form of democracy as portrayed in Venezuela's Constitution (see Ciccariello-Maher 2016; Ellner 2013; Harnecker 2010). The 2019 Constitution also emphasises the accountability of elected officials at the municipal, provincial and national levels, requiring them to give public account of their actions and subjecting them to potential removal from office, when they are not viewed to be responsive to the popular will.

In terms of creating the political instrument needed to lead the transition, Cuba's 2019 Constitution contains the tension that is evidenced in the

25 Burbach et al. (2013a: 144-5) warrant their view that Cuba represents a "unique model" by reporting that "Cubans draw a distinction between socialism in the twenty-first century and socialism of the twenty-first century (socialismo en el siglo 21 and socialismo del siglo 21). This difference in wording reflects the fact that the socialism being constructed in the rest of Latin America is unique to the new millennium, whereas in Cuba it has a much longer trajectory." 
characteristics of twenty-first-century socialism identified by Harnecker (2010, 2015). While, especially since 2008, Cuba has promoted consultations and other forms of bottom-up participation of citizens (Burbach et al. 2013) and, as noted just above, Cuba's 2019 Constitution encourages citizens' active participation in influencing and monitoring government policy and other decisions, the Constitution makes clear that the Communist Party of Cuba is accorded the role as "the superior driving force of society and the State" (Article 5).

In relation to the characteristic of instituting social ownership of the means of production, Cuba's 2019 Constitution presents a complicated picture. First, similar to frequently noted examples of twenty-first-century socialism (e.g. Bolivia, Venezuela), Cuba's 2019 Constitution makes explicit that not all - only the most important - means of production are to be socially owned; that is, there is space for a range of options including "private: that exercised on certain means of production by Cuban or foreign natural or legal persons" (Article 22, point "d"). Second, Cuba's 2019 Constitution is somewhat ambiguous about what it means for "all people" to own "the fundamental means of production" (Article 18). On one hand, Article 19 indicates that "[t]he State directs, regulates, and monitors economic activity", thus, resembling what Harnecker (2010: 44) suggests was characteristic of the "20th century socialism" of the Soviet Union. On the other hand, Article 20 emphasises that "[w]orkers participate in the processes of economic planning, regulation, management, and monitoring", a feature identified as a core of twenty-first-century socialism.

With respect to organising the economy toward satisfying buman needs, Cuba's 2019 Constitution reflects well this characteristic. Not only is the nature of Cuba's economic system presented being planned "according to the interests of society" (Article 18) and oriented to "reconciling national, territorial, collective, and individual interests for the benefit of society" (Article 19). In addition, Cuba's 2019 Constitution lays out in various articles a set of rights (e.g. education, healthcare, water, food, healthy environment) that are guaranteed to the Cuban people and which require that the economic system's results be devoted to satisfying these rights.

In terms of having a decentralised (but aggregating) planned economy including establishing worker-organised production and conceiving of efficiency that includes respect for nature and investment in full human development Cuba's 2019 Constitution measures up quite well. Cuba's "socialist economy" is defined as having a "planned direction" (Article 18), involving the state organs, workers and mass organisations (Articles 19 and 20). And while the overall plan must be approved by the national-level Assembly of People's Power, ideas for the plan stem from input at the municipal and provincial levels in legislative bodies as well as workplaces and mass organisations. The articles of 
Cuba's 2019 Constitution focused explicitly on the economic system do not call attention to "respect for nature" and "investment in full human development". However, other articles of the Constitution communicate a clear commitment to these as guaranteed rights of the Cuban people (respectively, Article 75 and Article 69).

In relation to incorporating material and moral incentives, Cuba's 2019 Constitution addresses explicitly the material incentive dimension for workers, specifying as rights "dignified employment" (Article 64) and to be "remunerated according to quality and quantity [of their work]" (Article 65). Elsewhere Cuba's 2019 Constitution gives attention to the importance of moral incentives when discussing one of the "essential purposes" of the state: "[t]o strengthen and preserve the ideology and the ethics inherent to our socialist society" (Article 13, point "g"). That over the 60+ years since the triumph of the Revolution in 1959 Cuba has had to refocus efforts to promote the importance of moral incentives indicates that Harnecker (2015: 91) understates the case when she comments that achieving cultural change toward emphasising moral incentives is something that "cannot be realized overnight".

With respect to educating for full human development and cultural transformation, Cuba's 2019 Constitution maintains the society's commitment to the right to education throughout life that is guaranteed and provided free of tuition charges by the state (Article 73). Furthermore, such education is to be focused on building citizens' knowledge and skills as well as continuing the process of transforming culture, specifically promoting socialist ideology and ethics.

In terms of building regional (and international) integration, Cuba's 2019 Constitution does not focus explicitly on regional integration but certainly highlights the importance of international solidarity. This solidarity is mentioned in the Preamble, which refers to "in proletariat internationalism, fraternal friendship, the help, cooperation, and solidarity of the peoples of the world". Internationalism is also discussed further in Article 16, identifying Cuba's "anti-imperialist and internationalist principles", including its "international duty to act with solidarity with the assaulted party and with the people who fight for their liberation and self-determination" (point " $j$ ") as well as its commitment to "[p]romote the protection and conservation of the environment as well as responding to climate change, which threatens the survival of the human species" (point "f $\mathrm{f}$ ").

And, finally in relation to transforming the role of the military, Cuba's 2019 Constitution discusses the military's role in protecting Cuba's sovereignty (Article 217). However, it also appears to define a broader role for the military of engaging in social projects and undertaking big infrastructure projects as part of its responsibilities for responding to disaster situations (Article 223). 


\section{References}

Aldama de Pino, Miguel Ángel, and Casañas Díaz, Mirta (2018) Filosofía de la Educación de Fidel Castro (1945-1981). Havana: Editorial Universitaria Félix Varela.

August, Arnold (2013) Cuba and its Neighbours: Democracy in Motion. London: Zed Books.

Azzellini, Dario (2013) "The communal state: Communal councils, communes, and workplace democracy", NACLA Report on the Americas, 46(2): 25-30.

Bellamy Foster, John (2010) "Foreword" [to special issues on Twenty-First Century Socialism: Inventing to Avoid Mistakes, by Marta Harnecker], Monthly Review, 62(3): iii-xvii.

Bishop, Maurice (1983) Maurice Bishop Speaks: The Grenada Revolution and its Overthrow, 1979-1983. New York: Pathfinder Press.

Burbach, Roger, Fox, Michael, and Fuentes, Federico (2013a) “Cuba: 'Updating' Twentieth-Century Socialism”, in Roger Burbach, Michael Fox and Federico Fuentes, Latin America's Turbulent Transitions: The Future of Twenty-First Century Socialism. London: Zed Books, 143-51.

Burbach, Roger, Fox, Michael, and Fuentes, Federico (2013b). Latin America's Turbulent Transitions: The Future of Twenty-First Century Socialism. London: Zed Books.

Campbell, Al (2018) “Cuba's co-operative sector and the project of deep reforms', in Sonja Novković and Henry Veltmeye (eds), Co-operativism and Local Development in Cuba: An Agenda for Democratic Social Change. Leiden: Brill, 160-78.

Campbell, Al (2021) "Evaluating against a multi-dimensional economic goal: A sustainable and prosperous socialism", International Journal of Cuban Studies, 13(1): 105-26.

Carnoy, Martin, Gove, Amber, and Marshall, Jeffery (2007) Cuba's Academic Advantage: Why Students in Cuba Do Better in School. Stanford, CA: Stanford University Press.

Castro Ruz, Fidel (1960). "Discurso en el Acto con los Empleados del Comercio", Havana, 5 June.

Ciccariello-Maher, George (2016) Building the Commune: Radical Democracy in Venezuela. London: Verso.

Cole, Mike (2012) "Twenty-first-century socialism and education in the Bolivarian Republic of Venezuela: An alternative to the neoliberal model”, in Ravi Kumar (ed.), Education and the Reproduction of Capital: Neoliberal Knowledge and Counterstrategies. New York: Palgrave Macmillan, 189-208.

Constitute Project (2019) Cuba's Constitution of 2019. Available at: https://www.constituteproject.org/constitution/Cuba_2019.pdf?lang=en.

Draper, Hal (1974) “Marx on democratic forms of government”, Socialist Register. Available at: https://socialistregister.com/index.php/srv/article/view/5326/2227.

DuRand, Cliff (2018) "Co-operatives in socialist construction”, in Sonja Novković and Henry Veltmeye (eds), Co-operativism and Local Development in Cuba: An Agenda for Democratic Social Change. Leiden: Brill, 100-9.

Ellner, Steve (2013) "Just how radical is President Nicolás Maduro", NACLA Report on the Americas, 46(2): 45-9.

Engels, Frederich (1880/1972) "Socialism: Utopian and scientific", in Robert Tucker (ed.), The Marx-Engels Reader. New York: W. W. Norton \& Co., 605-39. 
Fägerlind, Ingemar, and Saha, Lawrence (1983) "Education and development under capitalism and socialism", in Fägerlind and Saha, Education and National Development: A Comparative Perspective. Oxford: Pergamon Press, 195-233.

Faiola, Anthony (2019) "Socialism doesn't work? An emerging middle class of Bolivians would beg to differ", Washington Post (16 October): A10. Available at: https://www.washingtonpost.com/world/the_americas/socialism-doesnt-work-anemerging-middle-class-of-bolivians-would-beg-to-differ/2019/10/08/3b1cb3ae-e6f611e9-b0a6-3d03721b85ef_story.html.

Fidler, Richard (2015) “[Review of] Marta Harnecker's A World to Build: New Paths Toward 21st Century Socialism. [(translated by Federico Fuentes). New York: Monthly Review Press]", Monthly Review, 18 June. Available at: https://mronline. org/2015/06/18/fidler180615-html.

Fitz, Don (2020) Cuban Healthcare: The Ongoing Revolution. New York: Monthly Review Press.

Forman, J. (1973) Communism: From Marx's Manifesto to Twentieth-Century Reality. New York: New Viewpoints.

Garcia Batista, Gilberto (ed.) (2002, 2016) Compendio de Pedagogía. Havana: Editorial Pueblo y Educación, 36-44.

Gilbert, Jeremy (2020) Twenty-First Century Socialism. London: Polity Press.

Gill, Timothy (2016) “Whither Venezuelan Bolivarianism?”, NACLA Report on the Americas, 48(4): 367-71.

Ginsburg, Mark, and Garcia Batista, Gilberto (2019) "Reforming education and teacher education in Cuba: Revolución and perfeccionamiento", in Carlos Ornelas (ed.), Politics of Education in Latin America: Reforms, Resistance and Persistence. Rotterdam: Sense Publishers, 215-43.

Griffith, Tom, and Williams, Jo (2009) "Mass schooling for socialist transformation in Cuba and Venezuela", Journal for Critical Education Policy Studies, 7(2): 31-50.

Guevara, Ernesto Che (1973) "Man and socialism in Cuba”, in Bertram Silverman (ed.), Man and Socialism in Cuba: The Great Debate. New York: Atheneum.

Harnecker, Marta (2010) “Twenty-first century socialism: Inventing to avoid mistakes", translated by Janet Duckworth", Monthly Review, 62(3): 2-83.

Harnecker, Marta (2013) Conquering a New Popular Hegemony: Marta Henecker on Twenty-First ${ }^{t}$ Century Socialism. New York: Committees in Correspondence for Democracy and Socialism.

Harnecker, Marta (2015) A World to Build: New Paths toward Twenty-First Century Socialism (translated by Federico Fuentes). New York: Monthly Review Press.

Hetland, Gabriel (2016) "Chavismo in crisis: To stay in office, the Venezuelan government must address its major weaknesses", NACLA Report on the Americas, 48(1): $8-11$.

Hoogvelt, Ankie (1976) The Sociology of Developing Societies. London: Macmillan.

Howe, Irving (1977/1985) Socialism in America. San Diego, CA: Harcourt Brace Jovanavich.

Hudis, Peter (2020) "What is democratic socialism? What is socialist democracy? Review of 'True Democracy' as a Prelude to Communism: the Marx of Democracy by Alexandros Chrysis”, Socialist Studies/Études Socialistes, 14(1): 105-9. 
Lebowitz, Michael (2010) The Socialist Alternative: Real Human Development. New York: Monthly Review Press.

Leopold, Bruno (2020) "Karl Marx believed in democracy", Tribune. Available at: https:// tribunemag.co.uk/2020/10/marx-the-democrat/.

MacDonald, Theodore (1985) Making a New People: Education in Revolutionary Cuba. Vancouver: New Star Books.

Marx, Karl (1871/1972) “The civil war in France”, in R. Tucker (ed.), The Marx-Engels Reader. New York: W. W. Norton \& Co., 526-76.

Marx, Karl, and Engels, Frederich (1942) The German Ideology. London: International Publishers.

Marx, Karl, and Engels, Frederich (1848/1983) The Communist Manifesto. London: International Publishers.

Moulian, Tomás (2000) Socialismo del Siglo XXI: La Quinta Via. Santiago: Ed. Lom.

Pearce, Stephanie (2013) "Chávez in the Americas: Increasing autonomy in Latin America and the Caribbean", NACLA Report on the Americas, 46(2): 40-4.

Popular Unity Government (1971/2013) “Popular Unity Government: Basic Program”, NACLA: Report on the Americas, 46(3). Available at: https://nacla.org/article/popular-unity-government-basic-program.

Rosen, Fred (2013) "What was created? What remains?", NACLA Report on the Americas, 46(2): 22-4.

Ross, Clifton, and Rein, Marcy (2013) “The new socialism: Review of Latin America's Turbulent Transitions: The Future of Twenty-first Century Socialism (by Roger Burbach, Michael Fox, \& Federico Fuentes, London, Zed Books, 2013)", NACLA Report on the Americas, 46(2): 69-71.

Sustainable Development Index (n.d.) https:/www.sustainabledevelopmentindex.org/.

Tablada, Carlos (1989) "Incentive systems", in Che Guevara: Economics and Politics in the Transition to Socialism. Sydney: Pathfinder, 174-201.

Wolff, Richard (2019) Understanding Socialism. New York: Democracy at Work.

Yaffe, Helen (2020) We are Cuba! How a Revolutionary People have Survived in a PostSoviet World. New Haven: Yale University Press.

Zwerling, Philip, and Martin, Connie (1985) Nicaragua: A New Kind of Revolution. Chicago: Lawrence Hill Books. 